\title{
Borderline personality disorder: an adaptation of the Taiwan short version of the screening inventory into Brazilian Portuguese
}

\author{
Transtorno de personalidade borderline: uma adaptação para o português \\ brasileiro do inventário de rastreamento de Taiwan em sua forma reduzida
}

Thiago Coronato-Nunes, ${ }^{1}$ Vilma Aparecida da Silva-Fonseca, ${ }^{1}$ Samuel Ball, ${ }^{2}$ Azizi Seixas,${ }^{3}$ Girardin Jean-Louis,${ }^{3}$ Rollan Schoo Hirano, ${ }^{1}$ Thales Martins Parrot $^{1}$

\begin{abstract}
Objective: The current study presents the translation and adaptation of the 20-item Taiwan version of the Borderline Personality Inventory (BPI) into Brazilian Portuguese (BPI-P).

Methods: After translation and back-translation, the Brazilian Portuguese version was administered to three samples: patients with borderline personality disorder, psychiatric patients with comorbid substance use disorder and volunteers with no reported mental disorders.

Results: Significant differences between groups for borderline scores (analysis of variance [ANOVA], $F=52.923, p=0.01$ ) were found but there were no significant correlations between scores for borderline personality disorder and alcohol or nicotine dependence. The BPI-P had satisfactory validity for borderline personality disorder, even when anxiety and depression were present, with an area under the receiver operating characteristic curve of 0.931 at a cutoff point of 14 .

Conclusion: This study provides support for the potential utility of the BPI-P as a screening instrument for clinical practice in Portuguese speaking countries, including outpatients with alcohol and nicotine use disorders in early or sustained remission.

Keywords: Borderline personality disorder, inventory in Portuguese, diagnosis.
\end{abstract}

\section{Resumo}

Objetivo: Este estudo apresenta a tradução e adaptação do Inventário de Taiwan para Transtorno de Personalidade Borderline (IPB) de 20 itens, para o português brasileiro (IPB-P).

Métodos: Após tradução e retrotradução, a versão em português brasileiro foi aplicada em três amostras: pacientes com transtorno de personalidade borderline, pacientes psiquiátricos com comorbidade de transtorno de uso de substâncias e voluntários sem transtornos mentais relatados.

Resultados: Diferenças significantes entre os grupos em relação aos graus para borderline (análise de variância [ANOVA], $F=52,923, p=0,01$ ) foram encontradas mas não houve correlações significantes entre as pontuações para transtorno de personalidade borderline e dependência de álcool ou nicotina. O IPB-P teve uma validade satisfatória para transtorno de personalidade borderline mesmo quando ansiedade e depressão estavam presentes, com uma área sob a ROC (receiver operating characteristic curve) de 0,931 no ponto de corte de 14 .

Conclusão: Este estudo dá suporte para a utilidade potencial do IPB-P como um instrumento de rastreamento para a prática clínica em países de língua portuguesa, incluindo pacientes ambulatoriais com transtorno de uso de álcool e nicotina em remissão precoce ou sustentada.

Descritores: Transtorno de personalidade borderline, inventário em português, diagnóstico.

\footnotetext{
${ }^{1}$ Laboratório de Psiquiatria Translacional, Universidade Federal Fluminense, Niterói, RJ, Brazil. ${ }^{2}$ Yale University School of Medicine and the National Center on Addiction and Substance Abuse, New Haven, CT, USA. ${ }^{3}$ Department of Population Health and Center for Healthful Behavior Change, New York University School of Medicine, New York, NY, USA.

Submitted Mar 10 2017, accepted for publication Jul 172017.

Suggested citation: Coronato-Nunes T, Silva-Fonseca VA, Ball S, Seixas A, Jean-Louis G, Hirano RS, et al. Borderline personality disorder: an adaptation of the Taiwan short version of the screening inventory into Brazilian Portuguese. Trends Psychiatry Psychother. 2018;40(1):16-20. http://dx.doi.org/10.1590/22376089-2017-0071
} 


\section{Introduction}

A frequent problem in outpatient clinics including those for substance abuse is the diagnosis of personality disorders. The Diagnostic and Statistical Manual of Mental Disorders, 5th edition (DSM-5) requires that a patient is not using drugs before a personality disorder diagnosis is made. ${ }^{1}$ However, abstinence in programs for relapse prevention requires psychiatric care and treatment. ${ }^{2}$ Borderline personality disorder (BPD) is particularly interesting in this context: according to DSM-5, it starts in early adulthood, a time in which initiation of drug abuse also occurs, and is defined as a pervasive pattern of instability and marked impulsivity. Indeed, one of the diagnostic criteria for BPD is impulsivity, including substance abuse as one area of potentially self-damaging. Studies reported that BPD is a common disorder in drug treatment services and a challenge for mental professionals. ${ }^{3}$ A screening instrument for BPD would be useful in outpatient clinics, indicating which patients should be evaluated more extensively.

The diagnosis of BPD could also help in adhesion problems. Adhesion to treatment, as in any chronic medical condition, is a major factor in substance abuse treatment. Patients with BPDs may be very sensitive to real or imagined abandonment. In the busy outpatient clinic, a delay in assistance can mean abandonment or rejection, and adhesion will not occur. Actually, difficult attachment to professional help is described along with other DSM-5 diagnosis criteria. Another important issue is that BPD is hallmarked by intense and persistent dysphoria, leading to self-mutilation. ${ }^{1}$ It is important to identify these patients because even their pharmacological treatment will be different. Patients with BPD do not seem to be responsive to antidepressants even when affective symptoms are intensively present and severe enough to lead to suicide attempts or self-mutilation. ${ }^{4}$

Self-reported questionnaires and clinical interviews are the principal instruments in the diagnosis of personality disorders. Different cultures may present the same prevalence of personality disorders when questionnaires are translated and adapted. Cultural differences are important because personality disorder is defined as a pervasive pattern of behavior which deviates from the expectations of the individual's culture. Extreme differences have been studied, comparing western and eastern societies, and adaptation of western instruments to cultural differences were successful. ${ }^{5}$ Cultural differences may include beliefs in special powers to predict the future, difficulties in relationships and impulsivity are strongly influenced by cultural beliefs and cultural behavior and belong to the domain of BPD diagnosis. ${ }^{6}$

Among the instruments used to identify BPD, a reliable and valid semi-structured interview scale was developed by Gunderson et al., namely, the Diagnostic Interview for Borderline (DIB). ${ }^{7}$ However good for research purposes, it is too time-consuming for use in clinical settings. Short versions that rely on patient selfreport have also been developed, tested and translated into different languages. The Taiwan version ${ }^{8}$ of a selfreport version of the DIB has shown good reliability and validity and is short enough to be used as a screening instrument in clinical practice. The present study presents the adaptation of the Taiwan version of the Borderline Personality Inventory (BPI) into Brazilian Portuguese (BPI-P). Overlapping results of screening scales for depression, anxiety, alcohol and nicotine disorders were also considered.

\section{Methods}

The study was approved by the research ethics committee at Universidade Federal Fluminense (Niterói, state of Rio de Janeiro, Brazil).

The adapted scale (BPI) comprises 20 items which evaluate self-perception disturbances, interpersonal conflicts, affective and impulsive symptoms. It is a Thurstone scale with two options for each sentence (true or not true). Methods for adaptation of psychological instruments have been discussed elsewhere and were followed in the present study. ${ }^{9}$

\section{Translation and adaptation}

The English version was translated into Brazilian Portuguese by a bilingual professional, back-translated into English by another professional, and the two English versions were compared by a psychiatrist and a psychologist to check for discrepancies. One item had to be modified to improve precision of understanding. Table 1 presents the final version of the BPI-P.

Once the Brazilian Portuguese translation was ready, its adaptation for use in clinical practice and overlapping results with depression, anxiety, alcohol consumption and nicotine dependence scales were studied and are described below.

\section{Instruments}

In addition to BPI-P, volunteers were invited to fill the Beck Inventory for Depression, ${ }^{10}$ Beck Inventory for Anxiety, ${ }^{11}$ Alcohol Use Disorders Identification Test (AUDIT) ${ }^{12}$ and Fagerström Test for Nicotine Dependence. ${ }^{13}$ 


\section{Procedure}

A pilot study indicated that reading proficiency was necessary to fill the instruments. For this pilot study, a sample of 19 people invited at random among university students, patients from clinical specialties and cleaning employees of the university were submitted to the same procedure adopted in the following study. When difficulties of comprehension about the questions were manifested to researchers, or questionnaires were completed in a way that raised questions about reading proficiency, the respondent's schooling was evaluated. As a consequence of this pilot study, only undergraduate or graduate university students were included. This was therefore the first criterion for inclusion.

Table 1 - Original 20-item Taiwan version of the Borderline Personality Inventory (BPI) and the final Brazilian Portuguese version (BPI-P)

\section{Taiwan version \\ 1. Sometimes I feel like I am falling apart. \\ 2. I often wonder who I really am. \\ 3. I often feel a sense of worthlessness or hopelessness. \\ 4. Sometimes I feel a sense of not being real. \\ 5. Sometimes I act or feel in a way that does not fit me. \\ 6. I often don't know what I really want. \\ 7. I have intentionally done myself physical harm. \\ 8. Sometimes I feel guilty as if I had committed a crime, although I did not really commit one.}

9. I frequently experience panic spells.

10. I have attempted suicide.

11. Sometimes it is difficult for me to tell, whether something really happened, or whether it occurred only in my imagination.

12. In romantic relationships, I am often uncertain what kind of relationship I want.

13. My feelings towards other people quickly change to opposite extremes (e.g., from love and admiration to hate and disappointment).

14. Sometimes I feel a special sense of destiny (e.g., like a prophet).

15. If a relationship gets close, I feel trapped.

16. Sometimes I believe that I have a serious disease.

17. I feel smothered when others show deep concern towards me.

18. I often have the feeling that others laugh or talk about me.

19. If relationships become too close, I often feel the need to break them off.

20. In close relationships I am hurt again and again.

\section{Brazilian Portuguese version}

Às vezes eu sinto que estou desintegrando.

Eu muitas vezes gostaria de saber quem realmente sou.

Eu frequentemente me sinto inútil e sem esperança.

Algumas vezes eu sinto que não sou real.

Algumas vezes eu me comporto ou sinto de maneira oposta ao tipo de pessoa que eu penso ser.

Eu com frequência não sei o que realmente quero.

Eu já causei danos físicos a mim mesmo(a), intencionalmente.

Algumas vezes eu me sinto culpado(a), como se tivesse cometido um crime, embora eu realmente não tenha cometido um.

Eu frequentemente tenho sensações de pânico.

Eu já tentei suicídio.

Algumas vezes é difícil para mim dizer se alguma coisa realmente aconteceu, ou se ocorreu apenas na minha imaginação.

Em relacionamentos românticos, eu geralmente não tenho certeza de que tipo de relacionamento eu quero.

Meus sentimentos por outras pessoas mudam rapidamente para extremos opostos (por exemplo, de amor e admiração para ódio e desapontamento).

Algumas vezes eu sinto que tenho um dom sobrenatural especial que me permite perceber o que está para acontecer (por exemplo, como um profeta).

Se um relacionamento fica próximo, eu me sinto preso(a) como em uma armadilha.

Algumas vezes eu acredito que tenho uma doença grave.

Eu me sinto sufocado(a) quando outros mostram preocupações sérias sobre mim.

Eu muitas vezes sinto que os outros riem ou falam de mim.

Se os relacionamentos ficam muito próximos, eu geralmente sinto a necessidade de rompê-los.

Em relacionamentos próximos eu sou ferido(a) repetidas vezes.

Each sentence has two response options (true or not true). 


\section{Samples}

Three samples were evaluated in the main study:

- Sample 1: BPD patients $(n=16)$. Psychiatrists from private and public university clinics were asked to send patients followed up for a period superior to six months and to whom they would give a BPD diagnosis. After evaluation by one of the two psychiatrists in the research team, according to a clinical interview and a checklist for DSM-V criteria for BPD, 16 patients were included. No other instruments were used for the detection of BPD.

- Sample 2: psychiatric patients with other clinical diagnoses $(n=28)$. This sample comprised psychiatric patients with other diagnoses (BPD clinically excluded) from an outpatient clinic of the university directed to comorbid nicotine and alcohol use disorder. Patients fulfilling schooling criteria were invited and included after signing a consent form.

- Sample 3: university students without mental disorders and not receiving any psychiatric treatment $(n=60)$. Recruitment was carried out among students of the last year of medical school, invited in class to take part in a psychiatric health study.

\section{Instrument application}

All individuals signed an informed consent form. Volunteers were conducted to a private room where they received an envelope with all the instruments and were left alone with one researcher available to clarify any doubts. After filling the instruments, the envelopes were collected by the researcher and taken for analysis.

\section{Results}

Reliability among the 20 BPI-P items was estimated, and the Cronbach's alpha was 0.874.

Sample $1(n=16)$ had a mean \pm standard deviation score of $12.7 \pm 4.2$ in the borderline scale. Nearly two-thirds of these patients (63\%) scored above the cutoff point of 12 established for the Taiwan sample as indicating a likely diagnosis. In sample $2(n=28)$, the score was $9.5 \pm 4.4$, with $25 \%$ of the participants scoring above the Taiwan recommended cutoff. Finally, in sample $3(n=60)$, the mean score was $3.6 \pm 2.9$, and none of them scored above the Taiwan recommended cutoff score for possible BPD diagnosis.

The original Taiwan scale excluded depressive and anxious patients. In the present study, these patients were included, and the receiver operating characteristic (ROC) curve was estimated (Figure 1), suggesting a cutoff point of 14 (area under the curve $[A \cup C]=0.931$ ) when these disorders are included. Therefore, if BPI-P is to be used in samples of potentially depressed or anxious patients, this cutoff point will be more reliable. The cutoff point of 12 was adequate when only healthy and BPD volunteers were considered $(A \cup C=0.900)$.

In order to check if BPI-P would be able to distinguish between a borderline group and another psychiatric group when anxiety and depression are present, comparisons among groups were carried out. ANOVA analysis of the BPI-P scores obtained in the three groups was significant: $F_{(2.101)}=52.923, \mathrm{p} \leq 0.01$. Additional planned comparison between the two patient groups found that the BPD group scored higher than the psychiatric group: $t_{(43)}=2.363, \mathrm{p} \leq 0.03$. Significant Pearson correlation coefficients were found between the BPI-P score and anxiety $\left(r_{(104)}=0.651, \mathrm{p} \leq 0.01\right)$ and depression $\left(r_{(104)}\right.$ $=0.665, \mathrm{p} \leq 0.01)$. There was no significant correlation between AUDIT, Fagerström and BPI-P scores.

Beck depression scores (mean \pm SE) were, respectively: sample $1,11.9 \pm 1.1$; sample $2,18.8 \pm 1.7$;

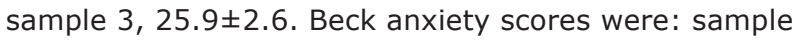
$1,7.92 \pm 0.898$; sample 2, $16.63 \pm 1.977$; sample 3, $26.00 \pm 2.678$.

Although gender was equally distributed in sample 3 (28 female, 32 male), there were proportionately more females than males in sample 1 and 2, i.e., proportions were very different in the psychiatric (27 female, 1 male) and borderline samples (13 female, 3 male).

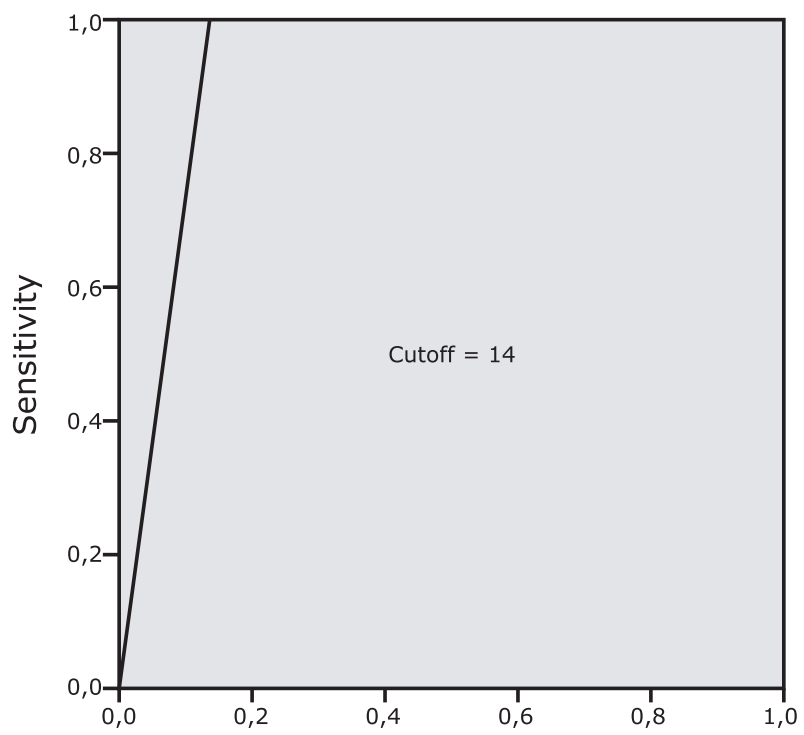

Figure 1 - Receiver operating characteristic $(R O C)$ curve for the BPI-P $(A \cup C=0.931)$. 


\section{Discussion}

Even though depression and anxiety often overlap with BPD, ${ }^{1}$ in the present study, the BPI-P was sensitive to distinguish between borderline patients and other psychiatric diagnoses. This could be seen in the statistical significant differences observed between the clinical groups. This result is important as depression and anxiety are confusing factors for BPD diagnosis. BPD patients may present anxiety when experiencing the symptoms of uncertainty about the self, instability and inadequacy. The study suggests that when depression or anxiety are clinically important, a higher cutoff point may increase specificity.

No statistical significant correlations were found between nicotine and alcohol consumption scales and the borderline scale. Patients were either in early or sustained remission. The implication of this result is that in relapse prevention services, when psychiatric diagnosis is essential for case management, ${ }^{2}$ the BPI-P may be useful.

The minimum necessary 5 years of education is a limiting factor, but not surprising for a self-evaluation questionnaire. Clinical evaluation is always the best approach to diagnosis, but easily self-applied scales, even before consultation, or applied in waiting rooms, can help the clinician choose better approaches and management. Further studies are still necessary to clarify the importance of gender in the diagnosis of BPD. The present study was limited in this aspect because of the high prevalence of females in the public outpatient psychiatric services.

In summary, we provide an adaptation to Brazilian Portuguese of the Taiwan version of the screening inventory for detection of BPD. A screening instrument for BPD would be useful in outpatient clinics, helping identify patients that should be evaluated more extensively.

\section{Acknowledgements}

We are grateful to Coordenação de Aperfeiçoamento de Pessoal de Nível Superior (CAPES) and Santander for financial support, and to volunteers who made the study possible. Authors also acknowledge the medical student Lucas Caroli for his valuable help.

\section{Disclosure}

No conflicts of interest declared concerning the publication of this article.

\section{References}

1. American Psychiatric Association. Diagnostic and Statistical Manual of Mental Disorders, Fifth Edition (DSM-5). Arlington: American Psychiatric Publishing; 2013.

2. Hendershot CS, Witkiewitz K, George WH, Marlatt GA. Relapse prevention for addictive behaviors. Subst Abuse Treat Prev Policy. 2011;6:17.

3. Schulz SC, Zanarini MC, Baterman A, Bohus M, Detke HC, Trzaskoma Q. Olanzapine for the treatment of borderline personality disorder: variable dose 12 week randomized doubleblind placebo controlled study. Br J Psychiatry. 2008;193:48592.

4. Bellino S, Paradiso E, Bogetto E. Efficacy and tolerability of pharmacotherapies for borderline personality disorder. CNS Drugs. 2008;22:671-92.

5. Yang J, McCrae RR, Costa PT, Yao S, Dai X, Cai T, et al. The crosscultural generalizability of Axis-II constructs: an evaluation of two personality disorders assessments instruments in the People's Republic of China. J Pers Disord. 2000;14:249-63.

6. Skodol AE, Gunderson JG, Pfohl B, Widiger TA, Livesley WJ, Siever IJ. The borderline diagnosis I: psychopathology, comorbidity and personality structure. Biol Psychiatry. 2002;51:936-50.

7. Gunderson JG, Kolb JE. Discriminating features of borderline patients. Am J Psychiatry. 1978;135:792-96.

8. Lee CY, Wen JK, Yeh WC, Lee Y, Chong MY. Reliability and validity of the 20-Item Taiwan version of the Borderline Personality Inventory. Chang Gung Med J. 2009;32:165-71.

9. Borsa JC, Damásio BF, Bandeira DR. Cross-cultural adaptation and validation of psychological instruments: some considerations. Paideia. 2012;22:423-32.

10. Gomes-Oliveira $\mathrm{MH}$, Gorenstein $\mathrm{C}$, Lotufo-Neto $\mathrm{F}_{\text {, Andrade }} \mathrm{LH}_{\text {, }}$ Wang YP. Validation of the Brazilian Portuguese version of the Beck Depression Inventory-II in a community sample. Rev Bras Psiquiatr. 2012;34:389-94.

11. Beck AT, Epstein N, Brown G, Steer RA. An inventory for measuring clinical anxiety: psychometric properties. J Consult Clin Psychol. 1988; 56:893-97.

12. Babor TF, Higgins-Biddle JC, Saunders JB, Monteiro MG; World Health Organization. Dept. of Mental Health and Substance Dependence. The Alcohol Use Disorders Identification Test. Guidelines for use in primary care. Geneva: World Health Organization, 2001.

13. Heatherton TF, Kozlowski LT, Frecker RC, Fagerström KO. The Fagerström Test for Nicotine Dependence: a revision of the Fagerström Tolerance Questionnaire. Br J Addict. 1991;86:111927.

\section{Correspondence:}

Thiago Coronato Nunes

Instituto Biomédico

Rua Prof. Hernani Melo, 101, sala 204-B, Bairro São Domingos

24210-130 - Niterói, RJ - Brazil

Tel.: + 55 (24) 981238959

E-mail: thiagocoronatonunes@gmail.com 